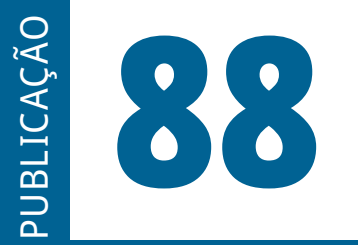

ISSN: 0101-9562

ISSN ELETRÔNICO: 2177-7055

SEQÜÊNCIA

Publicação do

Estudos jurídicos

e políticos

Programa de Pós-Graduação em Direito da UFSC

VOLUME 42 - ANO 2021 
SEQUÊNCIA - ESTUDOS JURÍDICOS E POLÍTICOS é uma publicação temática e de periodicidade quadrimestral, editada pelo Programa de Pós-Graduação Stricto Sensu em Direito da Universidade Federal de Santa Catarina - UFSC.

SEQUÊNCIA - ESTUDOS JURÍDICOS E POLÍTICOS is a thematic publication, printed every four months, edited by the Program in law of the Federal University of Santa Catarina - UFSC.

Versão eletrônica: http://www.periodicos.ufsc.br/index.php/sequencia

A publicação é indexada nas seguintes bases de dados e diretórios/

The Publication is indexed in the following databases and directories:

Base OJS

Base PKP

CCN (Catálogo Coletivo Nacional)

Dialnet

DOAJ (Directory of Open Access Journals)

EBSCOhost

Genamics Journalseek

ICAP (Indexação Compartilhada de Artigos de Periódicos)

Latindex

LivRe!

OJS
PKP
Portal de Periódicos UFSC
Portal do SEER
ProQuest
SciELO
Sherpa/Romeo
Sumarios.org
ULRICH'S
vLex

Ficha catalográfica

Seqüência: Estudos jurídicos e políticos. Universidade Federal de Santa Catarina.

Programa de Pós-Graduação em Direito. n.1 (janeiro 1980)-.

Florianópolis: Fundação José Boiteux. 1980-.

Publicação contínua

Resumo em português e inglês

Versão impressa ISSN 0101-9562

Versão on-line ISSN 2177-7055

1. Ciência jurídica. 2. Teoria política. 3. Filosoia do direito. 4. Periódicos.

I. Universidade Federal de Santa Catarina. Programa de Pós-graduação em

Direito

CDU 34(05)

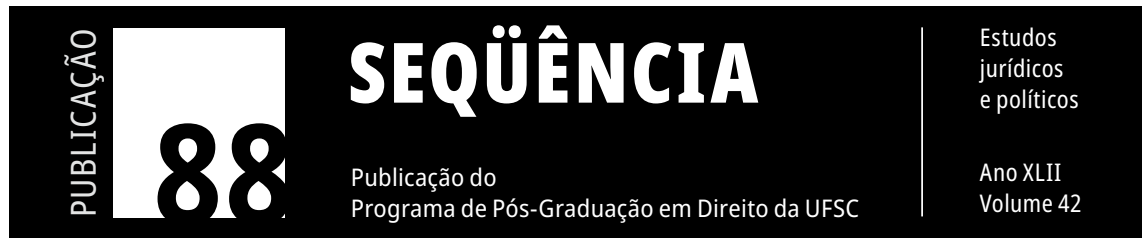




\section{The Inter-American Rule of Law in South American constitutionalism ${ }^{1}$}

\section{O Estado Interamericano de Direito no constitucionalismo sul-americano}

Carolina Cyrillo

Universidade Federal do Rio de Janeiro, Rio de Janeiro, Brazil. Universidade de Buenos Aires, Buenos Aires, Argentina

Édgar Hernán Fuentes-Contreras Universidad de los Andes, Santiago, Chile

Siddharta Legale

Universidade Federal do Rio de Janeiro, Rio de Janeiro, Brazil

ABSTRACT: The objective of this text is to present the modification of the conception of Rule of Law in the South America constitutionalism, from the dialogue and synergy between the Inter-American System of Human Rights and the new constitutions that emerged after dictatorships, authoritarian regimes, and internal wars, taking Operation Condor as a clandestine inter-American system or as unconventional status quo. We problematize how it is possible to speak of "Inter-American Rule of Law", which means the reconstruction of that State compatible with the ACHR in the Legislative, Executive and Judiciary spheres, as well the conventionality control and the standards emanating from the IACourtHR to laws, public policies, and national court decisions. Therefore, we defend the thesis that this dialogue can be the key to access the engine room of the constitutions, with the pro persona principle. The methodology used was a theoretical and normative

1 Acknowledgments. We would like to thank the professors and researchers of the Núcleo Interamericano de Direitos Humanos da Faculdade Nacional de Direito da UFRJ NIDH, Luiz Fernando Castilhos Silveira and Luiza Deschamps, for their grammatical and textual corrections and ideas to the original paper. 
approach, from a hypothetical deductive perspective and prioritizing as sources the bibliography and the caselaw of the IACourtHR.

KeYwORDS: Inter-American Rule of Law - Constitutional Law - South America - Conventionality Control

ResUmo: O objetivo deste texto é apresentar a modificação da concepção de Estado de Direito no constitucionalismo sul-americano, a partir do diálogo e sinergia entre o Sistema Interamericano de Direitos Humanos e as novas constituições que surgiram após ditaduras, regimes autoritários e guerras internas, tomando a Operação Condor como um sistema interamericano clandestino ou como um estado de coisas inconvencional. Problematizamos como é possível falar de "Estado de Direito Interamericano", o que significa a reconstrução daquele Estado compatível com a CADH nas esferas Legislativa, Executiva e Judiciária, bem como o controle de convencionalidade e os padrões que emanam da jurisprudência da CorteIDH para as leis, políticas públicas e decisões dos tribunais nacionais. Portanto, defendemos a tese de que este diálogo pode ser a chave para acessar a sala de máquinas das constituições, com o princípio pro persona. A metodologia utilizada foi uma abordagem teórica e normativa, a partir de uma perspectiva hipotético dedutiva e priorizando como fontes a bibliografia e a jurisprudência da CorteIDH.

Palavras-Chave: Estado Interamericano de Direito - Direito Constitucional América do Sul - Controle de Convencionalidade

\section{INTRODUCTION}

South American countries have very different regional contexts, with their own cultural characteristics, diverse traditions, and political organizations. It can be said that, with respect to colonization and post-colonial heritage, the history of the countries is similar in some respects and different in others, especially the Brazilian imperial experience, which is quite different from the history of other countries in the region.

However, after centuries of colonial exploitation, military dictatorships and internal wars, South American countries have asserted themselves as constitutional States governed by the rule of law and constitutional democracy as a reality. The constitutional 
process initiated in the 19th century, with advances and setbacks, is in firm consolidation ${ }^{2}$.

This late constitutional democracy has given rise to the emergence of movements of appreciation of constitutional law for the most diverse regional identities with the adoption of their own constitutional designs and has produced a plurality of institutes related to the organization of constitutional law.

Therefore, this study aims to question the concept of the rule of law that is drawn from the constitutional legal systems of South America, particularly the need to establish the normative hierarchy of international human rights treaties in domestic constitutional models specially after the transition processes between the years of terror and dictatorship to the new democracies

This transition involves a social discussion about the meaning of the dictatorship and its impact on politics and the national legal order, but also, the significance of this period for the international commitments assumed, already under democratic regimes, by these countries, especially the Inter-American Convention on Human Rights (ACHR).

Thus, we warn beforehand that it is impossible for us South Americans to talk about the rule of law, its concept, and dimensions, without considering the caselaw of Inter-American Human Rights System, and this implies the need to understand the rule of law from a new dimension arising through that interaction, or what we agree to call the Inter-American rule of law, a rule of law model based on conventionality control.

Therefore, the problem of the present research is an attempt to verify the possibility of the configuration of this rule of law, and the initial hypothesis is that there is a transformation of the State in South America from an authoritarian organization, based in the

2 On constitutionalism in the region see: FERREYRA, 2013; MARQUARDT, 2016; GARGARELLA, 2014; CYRILLO, 2021. 
transnational Operation Condor to an "Inter-American rule of law". The former is characterized as clandestine "Inter-American system", which means an illegal agreement between the region's dictatorships. The latter is an original and provocative concept to understand the dynamic between international human rights law and constitutional law. To prove or disprove the initial hypothesis we used doctrinal and documental basis, in a hypothetical deductive methodology that evaluates and reframes the Inter-American caselaw.

\section{RECONCEPTUALIZING CONSTITUTIONAL LAW IN SOUTH AMERICA}

The term constitutional law can have at least three meanings: (1) objective law that concretizes the fundamental organization of the powers of the State and grants the recognition of fundamental rights; (b) subjective individual, social or collective law or law of collective incidence; and (c) knowledge or science of the constitutional system of the democratic rule of law (Ferreyra, 2001, p. 74). Thus, the definition of constitutional law, at least in South America, must consider this inevitable "internationalization". (Cyrillo, 2013, p. 124).

The question is certainly complex, since the internationalization of constitutional law, or the constitutionalizing of international law, entails -no less- the need to revise the classic theories on sources and hierarchies of the basic fundamental legal norms of each national State and even to reconceptualize basic notions within the content of the concept of constitutional law itself (FErREYra, 2001, p.79).

The traditional doctrine of constitutional law, at least in Brazil, following Ingo W. Sarlet (2005, p. 54), establishes that the "constitutional rights" are the "rights of the individual", that "fundamental rights" are the rights of the human being recognized and positivized in the sphere of the positive constitutional law of a given State, while the expression "human rights", for its part, would be related to the 
international law, since it refers to those legal positions that recognize the human being as such, independently of its link to a given constitutional order and that, therefore, aspire to universal validity, for all peoples and all times, in such a way that they reveal an unequivocal supranational (international) character.

By the way, it is worth mentioning the warning of Diego A. Dolabjian (2017, p. 353), that the relationship of symmetry and reciprocity between constitutional law and human rights is still a bold proposal for some. From the referred correlation between human rights and fundamental rights, arises what Flávia Piovesan (1997, p. 45) calls "international constitutional law" or "fundamental human rights", understood as a fusion and interrelation between constitutional law and international law. Luigi Ferrajoli (2010, p. 37) also teaches that “are 'fundamental rights' all those subjective rights that correspond universally to 'all' human beings as endowed with the status of persons, of citizens or persons with the capacity to act."

Under this perspective, we do not propose a supra-state or a new international organization. We recognize this interaction as a special character of South American State to safeguard the same value, which is the pro persona principle, mentioned under article 29 of the American Convention on Human Rights, which demands the choice of the more protective source of law, or the more protective interpretation of legal norm based in the pro persona principle (Cerqueira, 2019).

With respect to the supra-state aspect, it is important to consider the development of a regional system for the protection of human rights, consisting of the Charter of the Organization of American States (OAS), the American Declaration of the Rights and Duties of Man, the American Convention on Human Rights (ACHR or "Pact of San José de Costa Rica"), and its additional protocol, the "Protocol of San Salvador".

The hierarchy of international human rights law under South American constitutional law has basically four constitutional models 
regarding the hierarchical position of international human rights treaties, according to Carolina Cyrillo (2013): (i) prevalence of international human rights law; (ii) equivalence or constitutional hierarchy of human rights treaties; (iii) supra-legal and infra-constitutional hierarchy and; (iv) constitutional normative silence.

The Colombian model is the model of prevalence of international human rights law, in the form of Article 93 of the Political Constitution of Colombia and the question of the block of constitutionality. The Argentine model is the model of equivalence or constitutional hierarchy of human rights treaties, in the form of Article 75, item 22 of the Constitution of the Argentine Nation. The Brazilian model is the model of supra-legal and infra-constitutional hierarchy, since the Supreme Federal Court (STF) erroneously interpreted the hierarchy of the American Convention on Human Rights (ACHR); and the Uruguayan model is the model of constitutional normative silence, which seems to indicate that the decision on the hierarchical position of international human rights law in relation to domestic law is reserved to the political appreciation of the opportunity and convenience of undervaluing or overvaluing international human rights norms (Cyrillo, 2019, p.81).

Certainly, the Uruguayan case is of extreme relevance to support the thesis of a reconceptualization of constitutional law in an objective sense in South America. In February 2011, the Inter-American Court of Human Rights (IACourtHR) condemned Uruguay in the Gelman vs. Uruguay case for the forced disappearance of María Claudia Gelman and the birth in captivity of her daughter Macarena Gelman, during the military dictatorship.

The Inter-American Court established that Uruguay had to remove any legal obstacle that allowed the impunity of those responsible for the facts. It considered that under Uruguayan law, the Expiry of the Punitive Claims of the State, enacted on December $22^{\text {nd }} 1986$, which prevented those who had committed serious human rights violations during the military dictatorship from being brought 
to trial, was devoid of legal effect, given its incompatibility with the American Convention on Human Rights and the Inter-American Convention on Forced Disappearance of Persons.

This law, which would have been approved and supported through two direct popular consultations, ended up being revoked through Law No. 18831, enacted on October $27^{\text {th }} 2011$, which restored the full exercise of the punitive claim of the Uruguayan State for crimes committed in application of State terrorism, fully complying with the decision of the Inter-American Court in prevalent application of the IACHR in the domestic sphere.

Specifically on the connection between the normative hierarchy of international human rights treaties in South American constitutions, it is imperative to highlight a series of judgments of the Inter-American Court of Human Rights (Inter-American Court or IACourtHR) addressed to countries in the region that show the importance of the issue for the construction of a new concept of constitutional law in South America (Cyrillo, 2021, p.29). These are the cases Barrios Alto v. Peru (2001); Moiwana Community v. Suriname (2005), Almonacid Arellanos v. Chile (2006), La Cantuta v. Peru (2006), Goiburu v. Paraguay (2006), Gomes Lund v. Brazil (2010), Gelman v. Uruguay (2011), Herzog v. Brazil (2018).

Analyzing this different models and Inter-American caselaw, Siddharta Legale (2019, p. 121) concludes that the ACHR is in fact a true Inter-American Constitution and the Inter-American Court become a Transnational Constitutional Court (Legale, 2020), which leads to the conclusion that the objective concept of constitutional law in South America deserves being updated to mean the fundamental organization of the powers of the State, which confers the recognition of fundamental rights, including those recognized by international human rights law, constitutional hierarchy, because nowadays it is impossible to envisage a South American State without the dialogue among Legislative, Executive and Judicial with OAS, IACHR and IACourtHR to implement the Inter-American 
standards, when they are more protective to the individual as the pro persona principle dictates ${ }^{3}$.

\section{THE AMERICAN CONVENTION ON HUMAN RIGHTS (ACHR) AS AN INTER-AMERICAN CONSTITUTION}

The caselaw of the Inter-American Court of Human Rights conceives the American Convention on Human Rights (ACHR) as controlling material, Inter-American corpus juris, conventionality block, supranational constitution of human rights, ius constitucionale commune, an inter-American constitution or simply a living, dynamic and evolving instrument that is a parameter for validity of legislation and State action. Besides this terminological battle, Siddharta Legale (2019) points out, this can be seen, for example, in the cases of Villagrán Moralares v. Guatemala (1999), Pueblo Bello v. Colombia (2006), Ituango v. Colombia (2006) and Cabrera García and Montiel Flores v. Mexico (2010).

In practice, the ACHR operates very much like a constitution, enjoying what Eduardo Ferrer Mac-Gregor has called "Conventional

3 We adopted the concept of the Transnational Constitutional Court in the sense of Siddharta Legale's doctoral thesis, having the following elements: (i) the Inter-American Court of Human Rights starts to behave as guardian of the American Convention on Human Rights; (ii) adopts the duty to carry out the concentrated control of conventionality in constructive and destructive, normative and factual ways (iii) InterAmerican caselaw is a precedent system or a "inter-American stare decisis", which consists, on the one hand, the binding force of the advisory opinions for the sentences and provisional measures and, on the other, in the res judicata of contentious cases is also binding to pending cases, unless the Court decides to overrule or distinguishing their own decisions expressly; and (iv) the Court assumes as her goal the protection of groups in situations of vulnerability due the failures of the national justice system; and (v) in historical terms and specifically within the inter-American system, the process of conventional mutation of the Inter-American Court of the 1980s called the Pedro Nikken Court can be observed, which has a profile from a classical Court of International Law to a Court in the years 90 and 2000 for a Constitutional Court, called "Cançado Trindade". For more details, see LEGALE, 2019; LEGALE, 2020 and LEGALE, 2021. 
Supremacy", which projects superior norms - especially those of jus cogens - that serve as a parameter for validity of the other norms. The parallelism with a constitution is appropriate, especially if this Constitution is conceived as a customary one, forged by the repeated practice of demanding its compliance and by the opinio juris of its binding nature, whose non-compliance entails international responsibility for those who signed it.

Overcoming the terminological battle related to the process of the constitutionalizing of the ACHR, the essential is to conceive of it as a kind of "harbor for sources of international law" or backbone responsible for interweaving customs, principles, and human rights treaties, as Siddharta Legale proposes (2019, p. 121).

Also note another typical function of the Constitutions: the other human rights treaties should be interpreted based on the normativity of the ACHR. In other words, not only customs are bound to the ACHR, but also other treaties. As an example, the right to life and the right to physical integrity, foreseen in articles $4^{\text {th }}$ and $5^{\text {th }}$ of the ACHR, were complemented by article 17 of Protocol II of the Geneva Conventions of 1949, which prohibits forced displacement of persons, notably in the case Mapiripán and Ituango v. Colombia (2006). The prohibition of slavery, provided for in article 6 of the ACHR, was complemented and further defined in Ituango v. Colombia (2006).

Various children rights, provided in article 19 of the ACHR, were complemented with the Convention on the Rights of the Child from 1989, as highlighted in the case Mapiripán v. Colombia (2005). The judicial guarantees, foreseen in article $8^{\text {th }}$ of the ACHR, now also include the right to consular assistance, foreseen in article 36 of the Vienna Convention on Consular Relations, as an indispensable element of the due legal process itself for it to be in accordance with human rights, as ruled in the case Castillo Petruzzi v. Peru (1999).

Therefore, the rights inherent to the human being must be interpreted, as the interpretative norms of the ACHR itself determines, 
through proposals that: i) promote progressive development (article 26); ii) localize the norms more favorable to the individual as demanded by the pro persona principle (article 29); iii) restrict rights only according to the law and in conformity with the purpose of the ACHR (article 30); and d) include other rights, in protection, not foreseen in the ACHR (articles 31, 76 and 77). The IACourtHR, therefore, provides thought its ruling the development of the interpretative standards that prevents the ACRH normativity from deterioration.

The Declaration of the Rights and Duties of Man also enters the conventionality block of the ACHR, acquiring binding force that it did not originally have, as the Inter-American Court of Human Rights recognized in its Advisory Opinion n. 10 ${ }^{\text {th }}$ of 1989. The Inter-American Democratic Convention ("ICC") of 2001 also joins the ACHR, reciprocally reinforcing the protection of political rights, as well as the inter-American concept of human rights.

\section{THE ROLE OF CONVENTIONALITY CONTROL AS A KEY TO OPEN THE ENGINE ROOM OF THE CONSTITUTION}

Conventionality control is conceived as a doctrine that aims for drawing a parameter of compatibility between state normative acts and domestic laws and the ACHR. Therefore, it can be described as "the act of analyzing the compatibility of domestic laws with the human rights treaties recognized by the States at the international level, having the ACHR as a parameter".

Thus, based on both the advisory and the litigious function of the Inter-American Court of Human Rights, several important precedents for the Inter-American System of Human Rights have been built up. For Nestor Pedro Sagüés (2011, p. 271), the destructive and constructive "control of conventionality" established by the InterAmerican Court of Human Rights orders national judges to consider as invalid the internal norms opposed to the American Convention 
on Human Rights and to consider the interpretation given to it by the Inter-American Court ${ }^{4}$.

The doctrine of conventionality control can be extracted from the case Barrios Altos v. Peru (2001), where for the first time a domestic norm was considered null and void by an international court, which annulled the effectiveness of a domestic norm - namely, the Peruvian amnesty laws, for finding it in violation of the ACHR.

It is not by chance that the doctrine of the conventionality control has been reinforced and consolidated in the case of the IACourtHR Almonacid Arellano v. Chile (2006), where it was reaffirmed that the laws of self-amnesty, besides being manifestly incompatible with the American Convention and devoid of legal effects, do not have any legal validity in the light of international human rights law.

In fact, as stated above, the connection between the amnesty laws and the respect for international human rights obligations seems to be a key in the construction of a model of constitutional law in South America that considers the idea of rule of law based on conventionality.

This conclusion is drawn from the decision in the case Almonacid Arellano v. Chile (2006), where domestic judges and courts, as well as the entire state apparatus, have a duty to be subject to the ACHR when a state ratifies the international treaty, which obliges them to ensure that the effects of the provisions of the ACHR are not diminished by the application of laws contrary to its object and purpose.

In other words, the accession and ratification of the treaty obliges them to exercise the "conventionality control" between the internal legal norms applied to concrete cases and the American Convention on Human Rights. In this task, the Judiciary, Legislative and Executive must consider not only the treaty, but also its interpretation by the

\footnotetext{
The term control of conventionality was introduced in the jurisprudence of the InterAmerican Court in the concurring opinion of Judge Sergio García Ramírez in the Myrna Mack Chang v. Guatemala case (2003). In this context, the motivation for evoking conventionality control was the Guatemalan state's failure to remove the obstacles to victims in the process and to ignore the negligence of the judicial bodies.
} 
Inter-American Court of Human Rights. If we destroy authoritarian perspectives and create public polices to improve the vulnerable people's rights, the people could also access the Engine Room of the Constitution State (GARGARELla, 2014) reconstructing the Rule of Law as a Rule of Law based on Conventionality (Fuentes-Contreras, 2019). The conventionality control, when protecting the minorities, could became a "key" to open this traditional constitutional structure that is closed or monopolized by the elites (AraúJo, 2020).

\section{OPERATION CONDOR: THE CLANDESTINE INTER-AMERICAN SYSTEM}

In the 50s, in a series of speeches recently compiled, at the Pan-American Union, Erico Verissimo tried to explain the need to understand the identities that united Latin America (South and Central America, as he understood) as a region marked by the domination of European conquerors, but that had developed with its inequalities and longed for a political legal integration for progress and development, identifying that the Inter-American unification was the goal of its liberation, since the times of Simón Bolivar, who was called by him as the founder of an idea of Inter-American integration or system (Bordini and Fauri, 2020, p. 190).

For Érico Verissimo, following in the footsteps of Bolivar, that was only possible through an Inter-American union. Recognizing the extreme inequality in Latin America and seeking its constant political and legal integration could consolidate the true dimension of respect for freedom, which was thriving in the 1950s in the region.

However, it was precisely during the period of military dictatorships in the region, a few years after Erico Verissimo's series of conferences, also in the second half of the 20th century, in the middle of the Cold War, where the political practices and the culture of those who occupied power, of repeatedly committing crimes such as torture, 
forced disappearance, kidnapping, and murder, was what brought the history of South American countries closer together.

The ideology of the dictatorship made the countries of South America experience a kind of "integration" not previously experienced and anchored by the National Security Doctrine and its norms. The so-called Operation Condor was created, a kind of supranational organization of state terror, which presupposed a military intelligence agreement between the countries of South America, including Argentina, Brazil, Bolivia, Chile, Paraguay, Uruguay, Peru, and Ecuador (PADrós, 2005, p. 64).

According to McSherry (1999) Operation Condor was organized as a true "Inter-American clandestine system", highly sophisticated in command, control, intelligence, prisoner exchange, and combined operations. It allowed the military to act with impunity in the associated countries and to use parallel clandestine structures to avoid accountability and maintain maximum secrecy. Those who were considered "suspects" were legally detained and could be transferred to the secret Condor system, where that person would "disappear", and the State could deny accountability and knowledge about the whereabouts of those people. Condor employed complex infrastructures and covert elimination mechanisms (such as burning bodies or throwing them overboard). The Condor apparatus bypassed the official judicial and penal structures of the States, which remained in place during military regimes, but without access to the system.

This "agreement" to relax the sovereignty of the States involved was made with the aim of ensuring ideological borders and not territorial ones (Chaves and Miranda, 2015, p. 523), as indicated by the National Security Doctrine (PADrós, 2008, p. 144) that sought in a common enemy, the supposed "communism", the support of its political and strategic base.

In effect, Operation Condor represented a true distortion of the Rule of Law and that Inter-American integration desired by Simón Bolivar and so well represented by Erico Verissimo, because 
the highest authorities of several countries agreed to cooperate in the enterprise of State terrorism, which consisted precisely in the total lack of protection of the human rights of their own citizens, as they conspired to violate international norms of protection such as the right to asylum, refugee protection, habeas corpus, as well as efforts to extradite those facing charges for crimes committed in one country and imprisoned in another.

As a secret treaty (Dinges, 2004, p. 41), Condor elevated crimes against human rights to the highest level of state policy, under the direct control of heads of state and ministers. The real Inter-American system in reverse, the "Mercosur of terror" (QuAdrat, 2002, p. 167), the real clandestine Inter-American system (McSherry (1999), articulated by the governing authorities of the South American countries.

This is the "unwanted" and "clandestine" integration of the South American States. Consists the contact point of integration by the regimes, trough the model of state action of terror cooperation, which in the future is reflected in the respective laws of amnesty made as a condition for the retaking of the democracies and that originated the transition from the dictatorial model of state terrorism to the new constitutional democracies of the region (CYRILLO, 2021, p.28).

This trace of the regional constitutionalism is felt and gains relevance for the discussion, already in the new democratic constitutions, about the role of international treaties on human rights, for the construction of the concept of a Rule of Law based on the respect to this conventionality.

In the transition process between the years of terror and the new democracies, amnesty laws were used for politically motivated crimes, with the idea that a re-democratization would only be possible if there was a pact for forgetting and forgiving of those politically motivated crimes.

This passage involves a social discussion about the meaning of the dictatorship and its impact on politics and the national legal order, but also, the significance of this period for the international commitments 
assumed, already in democratic regimes, by these countries, especially the Inter-American Convention on Human Rights (ACHR) ${ }^{5}$

\section{FROM UNCONVENTIONAL STATUS QUO TO INTER-AMERICAN RULE OF LAW}

This dictatorial or authoritarian past under "old wines in new bottles" that we call "Unconventional status-quo", persists even in the subsequent scenarios to the redemocratizations of the $80 \mathrm{~s}$ and $90 \mathrm{~s}$ that took place in South America. This concept does not exist in the caselaw of the Inter-American Court in those terms. It is an original proposal, formulated by Siddharta Legale and David Araújo Pereira (2016), which seeks to contribute to the construction of a perspective of action of the different instances and bodies involved in the protection of the person, having the ACHR as a parameter.

The proposal was inspired by the concept of the Unconstitutional status quo, coined by the Colombian Constitutional Court to highlight the need for more interventionist and direct action by the Judiciary in cases of massive, gross, and serious violations of fundamental rights protected by the Constitution of the State, persistent omission, and structural litigation. The leading cases were T-25/2004 and T-153. The first deals with the problems involving victims of forced displacement of persons and the second with people serving deprivation of liberty.

The primacy of the performance of the Inter-American Court would be directed towards cases that involve the ACHR more directly

\footnotetext{
Specifically on the subject, a series of judgments of the Inter-American Court of Human Rights (Inter-American Court of Human Rights) show that the relationship between amnesty laws and conventionality is key to thinking about the concept of conventional rule of law itself: Barrios Alto v. Peru (2001); Moiwana Community v. Suriname (2005), Almonacid Arellanos v. Chile (2006), La Cantuta v. Peru (2006), Goiburu v. Paraguay (2006), Gomes Lund v. Brazil (2010), Gelman v. Uruguay (2011), Herzog v. Brazil (2018).
} 
and that give rise to a deeper international intervention. These cases are those that would configure an "Unconventional State of Things" and would justify, by their nature, a more interventionist action by the Inter-American Court.

The growth of judicial activism in the performance of the Inter-American Court is obvious from 80s to 90 s and a 2000s. It is possible to see a "Pedro Nikken Court" in the 80s transitioning to a "Cançado Trindade Court" in 90s and 2000s (LEGALE, 2020b). The main purpose of this deeper judicial international intervention in to protect the Rule of Law, as made in the Constitutional Court v. Peru (2001), when Alberto Fujimori closed the Court and dismissed judges who tried to prohibit him from being re-elect for the third time, in violation the Peruvian Constitution. Also, Colombian cases such as the Mapiripán Massacre v. Colombia (2005), reveal an Unconventional Status quo, that requires a different attitude of judges and a new design of Inter-American Court.

The "Unconventional status quo" has three cumulative requirements that must be observed: (i) massive and repeated violation of human rights protected by the ACHR; (ii) repeated and persistent failure by States to bring a satisfactory solution to the dispute; and (iii) a structural dispute between the bodies directly responsible for presenting a possible solution to the problem.

The cycle of Brazilian cases involves the repeated omission of the Brazilian State, a massive violation of human rights, for example, of persons deprived of liberty and a lack of real and effective cooperation between the State Powers to provide an effective response to the very serious violations of human rights in Brazil (Legale, 2020, p. 281), such as Urso Branco (2002-2011), Araraquara (2006-2008), Curado (2014-2019), Pedrinhas (2014-2019), Febem (2005-2008), UNIS (2011-2017) and Damião Ximenes Lopes (2006-2021).

If these three assumptions are present, we recognize that the Court performs in an activist way that tries to revert the Unconventional Status quo, invalidating statutes and demanding public policies 
to try to protect human rights under Inter-American standards to construct or reconstruct the State to, what we call, an Interamerican Rule of Law.

The expansion of the Inter-American Human Rights System's constitutionalizing process advanced the cycle of Peruvian, Colombian, and Brazilian cases of the Inter-American Court of Human Rights (Legale, 2020, p. 103), strengthening a process of Inter-Americanization (AntoniazzI, 2016) of the State's norms, which encourages the creation of a national identity for multicultural and international integration in Latin America, of what can be called the "Conventional Rule Law” (Fuentes-Contreras, 2019).

The term "Conventional..." seems to restrict the protection to international treaties. Reevaluating the terminology, we point out that the term "Inter-American Rule of Law" is better, because it emphasizes the need of urgent dialogue among branches of State and the institutions of Inter-American Human Rights System, a fundamental point of constitutionalism in South America.

In institutional terms, therefore, the "Inter-American Rule of Law" means the reconstruction of that State compatible with the ACHR in the Legislative, Executive and Judiciary spheres, committed to the conventionality control and the standards emanating from the IACourtHR in the formulation of laws, public policies, and court decisions.

This new paradigm comprises the expansion of the concept of constitutional rule by spreading its strength and hierarchy to others that were not conceived by the original constituent, or by amendment, a posteriori (FuENTES-CONTRERAs, 2010). Its content encompasses international treaties, especially those that have the primary function of protecting human rights, as an Interamerican Constitution, considering the pro persona principle as its fundamental guideline.

In this sense, the conventionality control of norms and policies would no longer be attached only to the ACHR, but also to the advisory opinions, judgments, and provisional measures of the 
Inter-American Court, spontaneously within the internal scope of the States and independently of its international responsibility.

The Inter-American Court would have the power, therefore, to promote a more interventionist and necessary action in cases where the jurisdiction of the States has failed or proved to be inept in solving serious problems that require an immediate solution. This does not mean the imposition of imperative or authoritarian measures, but rather the promotion of a more intense dialogue, to bring both spheres closer together and to seek a more effective and satisfactory solution (FUENTESContreras y Cárdenas-Contreras, 2021). The intensification of the dialogue among IACHR and IACourtHR and States branches could be considered an important transformation, a "conventional mutation" or reframing of the Rule of Law to an Inter-American Rule of Law

\section{CONCLUSION}

The present paper aimed to verify the possibility of the configuration of the Inter-American Rule of Law from the observation of the synergistic and dynamic relationship between international human rights law and constitutional law, especially in South America.

To support this idea, we first chose to work with the identity of regional history. In the 1970s in South America, only Colombia and Venezuela were not ruled by a military or authoritarian government (although Colombia was emerging from a restricted political regime and faced an armed conflict). In the other countries, a kind of supranational organization of state terrorism was created, which presupposed a military intelligence agreement between Argentina, Brazil, Bolivia, Chile, Paraguay, Uruguay, Peru, and Ecuador, as the real "clandestine inter-American system," an agreement to flexibilize national sovereignty for the cooperation of state terrorism, which consisted of a total lack of protection of the human rights of its own citizens. It was Operation Condor. 
This dictatorial or authoritarian past under what we call the "unconventional status quo" basically consisted of (i) massive and repeated violations of protected human rights; (ii) repeated and persistent failures of states to bring a satisfactory solution to the dispute; and (iii) a structural dispute between the bodies directly responsible for presenting a possible solution to the problem.

This shared history gave rise to the discussion on the role of the international human rights protection system, in particular the hierarchical relationship between constitutional law and the regional human rights protection system; the role of the American Convention on Human Rights (ACHR) as the Inter-American Constitution and the jurisdiction of the Inter-American Court of Human Rights.

Specifically on the connection between the normative hierarchy of international human rights treaties in South American constitutions, an important series of rulings by the Inter-American Court of $\mathrm{Hu}-$ man Rights show the importance of the issue for the construction of a new concept of constitutional law. These are the cases Barrios Alto v. Peru (2001); Moiwana Community v. Suriname (2005), Almonacid Arellanos v. Chile (2006), La Cantuta v. Peru (2006), Goiburu v. Paraguay (2006), Gomes Lund v. Brazil (2010), Gelman v. Uruguay (2011), Herzog v. Brazil (2018).

By analyzing these models and the Inter-American caselaw, it is possible to conclude that the ACHR is indeed a true Inter-American Constitution and that the Inter-American Court has become a Transnational Constitutional Court, which leads to the conclusion that the objective concept of constitutional law in South America deserves an update to mean the fundamental organization of the powers of the State, which confers the recognition of fundamental rights, including those recognized by international human rights law with constitutional hierarchy.

It is impossible to think of a South American State without the dialogue and synergy between the Legislative, Executive and Judiciary with the OAS, the IACHR and the IACHR to implement 
the Inter-American norms, when they are more protective for the individual, as determined by the pro persona principle. This is the control of Conventionality conceived as a doctrine that aims to draw a parameter of compatibility between the norms and the pro persona principle, established in the interpreted ACHR.

In other words, the adhesion and ratification of a treaty obliges us to exercise "Conventionality Control" between the internal legal norms applied to concrete cases and the American Convention on Human Rights. In this task, the Judiciary, Legislative and Executive branches must consider not only the treaty, but also the interpretation made by the Inter-American Court of Human Rights. If we destroy authoritarian perspectives and create public policies to improve the rights of vulnerable people, it will also be possible to access the engine room of the Constitution, reconstructing the Rule of Law as a Rule of Law based on Conventionality. Conventionality control, by protecting minorities, could become a "key" to unlock this traditional constitutional structure.

The expansion of the Inter-American System strengthening a process of Inter-Americanization of State norms encourages the creation of a regional identity of multicultural and international integration in South America, which can be called "Conventional Rule of Law". However, this nomenclature, it seems, restricts protection to international treaties and does not give the true dimension of dialogue and synergy with constitutional law. Revaluing the terminology, we emphasize that the term "Inter-American Rule of Law" is more representative, as it emphasizes the need and the urgent dialogue between the branches of the State and the institutions of the Inter-American Human Rights System, a fundamental point of constitutionalism in South America.

In institutional terms, therefore, the "Inter-American Rule of Law" means the reconstruction of that ACHR-compatible State in the Legislative, Executive and Judicial spheres, committed to conventional control and to the norms emanating from the Inter-American system, in the formulation of laws, public policies and judicial decisions. 
This new paradigm comprises the expansion of the concept of constitutional norm, spreading its strength and hierarchy to others that were not conceived by the original constituent, or by constitutional reform. Its content encompasses international treaties, especially those that have the primary function of protecting human rights, such as the Inter-American Constitution, considering the pro persona principle as a fundamental guideline.

\section{BIBLIOGRAPHY}

ANTONIAZZI, Mariela Morales. O Estado Aberto: Objetivo do Ius Constitutionale Commune em Direitos Humanos. In: Coordenadores: Armin Von Bogdandy, Mariela Morales Antoniazzi e Flávia Piovesan (Coords). Ius Constitutionale Commune na América Latina - Volume I - Marco Conceptual Coleção Direitos Humanos e Constitucionalismo Regional Transformador Curitiba: Juruá, 2016, p. 53.

ARAÚJO, David Pereira de Araújo. O Bloco de Constitucionalidade no Novo Constitucionalismo Sul-Americano: uma chave para entrar na sala de máquinas? Dissertação (Mestrado em Direito Constitucional). Programa de Pós-graduação stricto sensu em Direito Constitucional. Universidade Federal Fluminense, Niterói, Rio de Janeiro, 2020.

BOGDANDY, Armin von. Ius Constitutionale commune na América Latina. Uma reflexão sobre o constitucionalismo transformador. Revista de Direito Administrativo, n. ${ }^{\circ}$ 269, 2015, p. 13-66.

BORDINI, Maria da Gloria e FAURI, Ana Letícia (orgs.). Erico Verissimo Cartas da União Pan-Americana 1953/1958. Rio de janeiro: Makunaima, 2020.

CHAVES, João Guilherme Pereira e MIRANDA João Irineu de Resende. Terror de Estado e Soberania: Um Relato sobre a Operação Condor, in Passagens. Revista Internacional de História Política e Cultura Jurídica. Rio de Janeiro: vol. 7, no .3, setembro-dezembro, 2015.

COSTA, Wanderley Messias da. Crise da integração e tendências geopolíticas na América do Sul. In. COSTA, Wanderley Messias da e VASCONCELOS, Daniel Bruno (orgs.) Geografia e Geopolítica da América do Sul: Integração e conflitos. São Paulo: FFLCH/USP, 2019. 
CYRILLO DA SILVA, Carolina Machado. La posición jerárquica del Derecho Internacional de los Derechos Humanos en las Constituciones Sudamericanas. In Contextos n. 5, Buenos Aires, 2013.

CYRILLO DA SILVA, Carolina Machado. Os quatro modelos da posição hierárquica do direito internacional dos direitos humanos nas constituições dos países da América do Sul. In: NASCIMENTO, Valéria Ribas e SALDANHA, Jania Maria Lopes. Os Direitos Humanos e o constitucionalismo: espectros da DUDH e da Constituição da república Federativa do Brasil. Rio de Janeiro: Lumen Juris, 2019.

CYRILLO, Carolina. O Constitucionalismo Sul-Americano: uma introdução. In, PEDRA, Adriano Sant'Ana et all. Perspectivas Latino-Americanas sobre o Constitucionalismo no Mundo. Belo Horizonte: Conhecimento editora, 2021.

DINGES. John. Os Anos do Condor - Uma Década de Terrorismo Internacional no Cone Sul. São Paulo: Cia. das Letras, 2004.

DOlABJIAN, Diego A. Derecho Constitucional Profundizado. Buenos Aires: Ediar, 2017.

FERRAJOLI, Luigi. Constitucionalismo principialista y constitucionalismo garantista. In Doxa: Cuadernos de filosofía del derecho, ISSN 0214-8676, $\mathrm{N}^{\circ}$ 34, 2011, págs. 15-54;

FERRAJOLI, Principia Iuris. Teoría del derecho y de la democracia, Madrid: trotta, 2007.

FERRAJOLI. Luigi. Costituzionalismo principialista e costituzionalismo garantista, IN Giurisprudenza costituzionale, Milano: Giuffre, Vol. 55, № 3 , 2010, págs. 2771-2816.

FERREYRA, Rául Gustavo. Fundamentos Constituicionales. Buenos Aires: EDIAR, 2013.

FERREYRA, Rául Gustavo. Notas sobre derecho constitucional y garantías. Buenos Aires: Ediar, 2001.

FUENTES CONTRERAS, Édgar Hernán. Del Estado constitucional al Estado convencional de Derecho. Estudio Preliminar sobre el modelo del Estado Convencional de Derecho, en el contexto latino-americano. In Revista jurídica Digital UANDES 3/2, 2019, p. 13-42. http://dx.doi. org/10.24822/rjduandes.0302.2. 
FUENTES-CONTRERAS, Édgar Hernán y CÁRDENAS-CONTRERAS, Luz Eliyer, Deferencia a la soberanía nacional. Práctica y doctrina del margen de apreciación nacional en el Sistema Interamericano de Derechos Humanos. In Anuario Mexicano de Derecho Internacional 21, 2021, pp. 197-231. http://dx.doi.org/10.22201/iij.24487872e.2021.21.15592.

FUENTES-CONTRERAS, Édgar Hernán. Materialidad de la Constitución. Bogotá, D.C.: Grupo Editorial Ibáñez y otro, 2010.

GARGARELLA, Roberto. Democracia, representación y participación política. In GARGARELLA, Roberto (cord.) La constitucion en 202048 propuestas para una sociedad igualitária. Buenos Aires: siglo veintiuno, 2011. P. 228-229.

GARGARELLA, Roberto. La sala de máquinas de la constitución. Dos siglos de constitucionalismo em américa latina (1810-2010). Buenos Aires: Katz, 2014.

LEGALE, Siddharta. La Constitución Interamericana: Los 50 Años de la Convención Americana sobre Derechos Humanos en la Jurisprudencia de la Corte Interamericana de Derechos Humanos. In: OEA. (Org.). Curso de Direito Internacional XLVI. 1ed. Rio de Janeiro: OEA, 2019, v. 1 , p. $121-171$.

LEGALE, Siddharta. A Corte Interamericana de Direitos Humanos como Tribunal Constitucional. Rio de Janeiro: Lumen Juris, 2020.

LEGALE, Siddharta . A Corte Interamericana de Direitos Humanos nos anos 80: Uma "Corte" Pedro Nikken?. In, Anuário Mexicano de Derecho Internacional, v. XX, p. 315-349, 2020 b.

LEGALE, Siddharta. A Corte Interamericana de Direitos Humanos nos anos 90 e 2000: uma "Corte" Cançado Trindade? [The Inter-American Court of Human Rights in the 1990s and 2000s: a Cançado Trindade "Court"? ] In: LEGAlE, Siddharta (Org). Temas de Direitos Humanos [ Human Rights Essays]. Rio de Janeiro: NIDH - UFRJ, 2021.

LEGALE, Siddharta. Internacionalização do direito: reflexões críticas sobre seus fundamentos teóricos. REVISTA DA SJRJ , v. 20, p. 109-142, 2013.

LEGALE, Siddharta; ARAÚJO, David. O Estado de Coisas Inconvencional: trazendo a Corte Interamericana de Direitos Humanos para o debate sobre o sistema prisional brasileiro. In, Revista Publicum, v.2, n. ${ }^{\circ} 2,2016$. 
MARQUARDT, Bernd. Historia Constitucional Comparada de Iberoamérica. Las seis fases desde la revolución de 1810 hasta la transnacionalización del siglo XXI. Bogota: Ibañez, 2016.

McSHERRY, J. Patrice. Operation Condor: Clandestine Inter-American System. In Shadows of State Terrorism: Impunity In Latin America. Social Justice: 1999 , p. 144-174.

MELlO, Patrícia Perrone Campos. Constitucionalismo, transformação e resiliência democrática no Brasil: o Ius Constitucionale Commune na América Latina tem uma contribuição a oferecer?. Revista Brasileira de Políticas Públicas, Brasília, v. 9, n. 2 p.253-285, 2019.

MOREIRA, Constanza. Resistencia Política y Ciudadanía: Plebiscitos y Referéndums en el Uruguay de los '90. América Latina Hoy, 36, Salamanca: Universidad de Salamanca, 2004. pp. 17-45.

PADRÓS, Enrique Serra. Como el Uruguay no hay ... Terror de Estado e segurança nacional Uruguai (1968-1985): do Pachecato à ditadura civil-militar. Tese (Doutorado em História). Porto Alegre: Programa de Pós-Graduação em História - Universidade Federal do Rio Grande do Sul, 2005.

PADRÓS, Enrique Serra. Repressão e violência: segurança nacional e terror de Estado nas ditaduras latinoamericanas. In: ARAUJO, Maria Paula Nascimento; FERREIRA, Marieta de Moraes; FICO, Carlos; QUADRAT, Samantha Viz (orgs.). Ditadura e Democracia na América Latina. Rio de Janeiro: Editora FGV, 2008.

PIOVESAN, Flávia. Direitos Humanos e o Direito constitucional Internacional. $2^{a}$ ed. São Paulo: Max Limonad, 1997, p. 45.

PIOVESAN, Flávia. Temas de direitos humanos. 8 ed. São Paulo: Saraiva. 2015. p.196.

QUADRAT, Samantha Viz. Operação Condor: o 'Mercosul' do terror. In: Estudos Ibero-Americanos. PUCRS, v. XXVIII, n. 1, jun. 2002, pp. 167-182. SAGÜÉS, Nestor Pedro. Obligaciones internacionales y control de convencionalidad: international obligations and "conventionality control". In: Instituto de Justicia Constitucional (Guatemala). Opus Magna Constitucional Guatemalteco. Cidade da Guatemala: Corte de Constitucionalidad, 2011. p. 271-291. Disponível em: https://www.corteidh.or.cr/tablas/28053-11. pdf. Acesso em: 22 jan. 2021 
SARLET, Ingo Wolfgang. A eficácia dos direitos fundamentais. 5. ed. Porto Alegre: Livraria do Advogado, 2005.

TERRILE, Ricardo Alejandro. Estado constitucional e convencional de direito. E-book Kindle, 2017.

\section{CAROLINA CYRILLO}

Adjunt professor of Constitucional and Administrative Law at Federal University of Rio de Janeiro (UFRJ), Brasil and lecturer in constitucional law at the University of Buenos Aires (UBA), Argentina. Coordinator of the Inter-American Human Rights Center (@NIDHFND), and of investigation project South American constitutionalism (@sudfnd).PhD candidate at University of Rio de Janeiro and University of Buenos Aires. Master in theory and philosophy of law at University of Santa Catarina (UFSC). Lawyer. Professional Address: R. Moncorvo Filho, No 8 Rio de Janeiro, RJ (Brasil).

ORCID ID: https://orcid.org/0000-0003-2783-8025

E-MAIL: carolmcys@gmail.com

\section{ÉDGAR HERNÁN FUENTES-CONTRERAS}

Postdoctoral Researcher at Universidad de Los Andes, Chile. Doctor, with international mention, and Master in Constitutional Law from the University of Sevilla; Master in Law from the University Nacional of Colombia; specialist in Constitutional Law from the University Externado of Colombia and lawyer from the University of Antioquia. He has completed updating studies at the University of Buenos Aires and research stays at the University Nacional de La Plata and the University of Sevilla. Professor, academic peer, researcher and author. Founding Member of IIDH-Colombia, Director for Colombia Latin Iuris, Associate of IDEI-Bolivia, among others. 
Among his works are "Materialidad de la Constitución" (Ibáñez, 2010, 2016), "Legislación en sentido material” (Ibáñez, 2018) and "Método(s) y Derecho(s)" (Tirant, 2021).

Professional address: Cl 57 6-13 Bogotá, D.C. (Colombia).

ORCID ID: https://orcid.org/0000-0002-1066-0999

E-mAIL: edgar.fuentes@miuandes.cl; edherfucon@gmail.com

\section{SIDDHARTA LEGALE}

Constitutional Law and Human Rights Professor at the Federal University of Rio de Janeiro (UFRJ). Visiting Professor of the Masters in Constitutional Law at UFF. Coordinator of the Inter-American Human Rights Center (@NIDHFND) and the Inter-American Human Rights Clinic at UFRJ (@ClínicaIDHUFRJ) and the NIDH Casoteca (@casotecadonidh). Post-doctor and PhD in International Law from the State University of Rio de Janeiro (UERJ). Master in Constitutional Law and Bachelor from the Fluminense Federal University (UFF). Lawyer.

Professional address: R. Moncorvo Filho, No 8 Rio de Janeiro, RJ (Brasil)

ORCID ID: https://orcid.org/0000-0002-7472-3469

E-MAIL: siddhartalegale@hotmail.com

Received: 2021.08.18

Accepted: 2021.10.09 


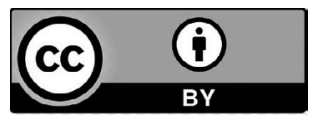

This work is licensed under a Creative Commons Attribution 4.0 International License.

LICENSE TO USE: Authors grant Sequência Journal exclusive rights of first publication, and the work is licensed under the Creative Commons Attribution 4.0 International License. The license authorizes third parties to remix, adapt, and/ or create from the published work, indicating credit to the original work and its initial publication. The authors are allowed to enter into additional separate agreements, with non-exclusive distribution of the version published in Sequência Journal, indicating, in any case, authorship and initial publication in this journal. 